\title{
Microbiological quality of well water in Kalutara District
}

\author{
S Kushlani Jayatilleke ${ }^{1}$ and S Shyamalee V Gunawardana ${ }^{1}$ \\ (Index words: water quality, microbiology, Escherichia coli, well water)
}

\begin{abstract}
Objective To investigate the microbiological quality of well water in the Kalutara district.

Method A retrospective analysis was carried out of reports on water samples taken from tube wells, protected wells and unprotected wells in Kalutara district in 2007. Information was obtained from laboratory registers and request forms.
\end{abstract}

Results In 2007, the microbiological quality of 185 samples of well water had been tested. Of these, 120 $(64.86 \%)$ were unsuitable for consumption, and 106 $(57.3 \%)$ samples were contaminated with Escherichia coli.

Conclusions A high percentage of well water samples tested from the Kalutara District were unsuitable for consumption, with over half contaminated with Escherichia coli.

\section{Introduction}

The year 2008 was declared as International Year of Sanitation by the World Health Organisation (WHO). Provision of an adequate supply of safe drinking water is one of the main aims of proper sanitation. On average, as much as one-tenth of a person's productive time is wasted due to disease resulting from consumption of contaminated water. About $77 \%$ of the population of Kalutara district in Sri Lanka, use well water as their main source of drinking water [1]. According to the WHO, non-pipe borne water supplies, including water from wells or springs, may often be contaminated with pathogens [2]. Water from such sources often requires treatment and protected storage in order to be safe for consumption [2].

There are very few published studies on microbiological quality of well water in Sri Lanka [3]. A study in the Kurunegala district in 1987-1988 [4], found that 60\% of people used protected wells, 30\% used unprotected water sources, and $10 \%$ used hand pumps and piped water supplies. In this study the proportion of contaminated samples was high, with the exception of piped supplies and water from hand pumps. The faecal coliform count was highest in water from unprotected sources [4].

This study was undertaken to evaluate microbial contamination of well water in the Kalutara district.

\section{Methods}

A retrospective analysis of laboratory data on water samples taken from tube wells, protected wells and unprotected wells in the Kalutara district was carried out. Information was obtained from laboratory registers and request forms, and analysed manually.

Water samples, which were collected following a standard procedure in sterile bottles were brought to the laboratory within 2 hours of collection or in ice packs if later by Public Health Inspectors trained in the collection and transport of water samples. Presumptive coliform counts and $E$. coli counts were determined using the multiple tube method. On the first day $10 \mathrm{ml}$ and $1 \mathrm{ml}$ of each sample were inoculated into 5 tubes of double strength and 5 tubes of single strength MacConkey Broth, respectively. $1 \mathrm{ml}$ of a 1 in 10 dilution of each sample was also added to 5 tubes of single strength MacConkey Broth. Tubes were incubated for 24 to 48 hours at $37^{\circ} \mathrm{C}$, and observed for gas and turbidity. The number of tubes positive for gas and turbidity for each sample were read according to the MPN table and presented as the total coliform count per $100 \mathrm{ml}$. The positive tubes were then sub-cultured to Brilliant Green Bile Broth and Tryptone Water, and incubated at $44^{\circ} \mathrm{C}$ for 24 to 48 hours. Kovac's reagent was added to the Tryptone Water tubes and mixed. Appearance of a red ring at the upper layer indicates a positive indole test. The number of tubes with production of gas at $44^{\circ} \mathrm{C}$ and a positive indole test was taken as being positive for $E$. coli, and the count was read according to the MPN table. The results were interpreted by a Consultant Microbiologist using the Sri Lanka Standard 614: Part 2:1983 with amendments approved in 1988 [6].

\section{Results}

The microbiological quality of 185 samples of well water from the Kalutara district was tested in 2007. Of these, $120(64.86 \%)$ were unsuitable for consumption, and $106(57.3 \%)$ were contaminated with E. coli, indicating recent faecal pollution.

\section{Discussion}

The WHO recommended indicator organism of choice for faecal pollution is E. coli. Water intended for

${ }^{1}$ National Institute of Health Sciences, Kalutara, Sri Lanka.

Correspondence: SKJ, e-mail <kush_jaya@yahoo.co.uk>. Received 26 July 2008 and revised version accepted 27 February 2009. Competing interests: none declared. 
human consumption should not contain E. coli [5]. We found that nearly two thirds of water samples from wells in the Kalutara district were microbiologically unsuitable for human consumption. A survey undertaken by the Department of Census and Statistics in Sri Lanka in 2006 to 2007 concluded that $86 \%$ of households in Sri Lanka use safe drinking water [3]. This was on the assumption that water from protected wells, and tube wells and pipeborne water is safe. However, protected wells may have microbial contamination even though they are protected at the ground level. A survey done in tsunami affected areas of the Southern Province of Sri Lanka showed that $80 \%$ of people were satisfied with the provision and quality of drinking water [6]. However, a study carried out in the Matara district using a field test kit for $\mathrm{H}_{2} \mathrm{~S}$ has shown that water obtained from $65 \%$ of dug-up wells and $100 \%$ of tube wells has faecal contamination [7]. This data is comparable to ours, although we could not obtain information of the type of wells from which our water samples were obtained.

There is no planned protocol for sampling of well water for microbiological analysis in Sri Lanka. Though there is an understanding that water samples from the Kalutara district should be sent to the Laboratory of National Institute of Health Sciences for microbiological testing, there is no proper mechanism to monitor it.

\section{Conclusion}

Most well water samples tested from the Kalutara district were unsuitable for human consumption. The community should be educated regarding the high possibility of contamination of well water and the importance of boiling or otherwise treating water before consumption.

\section{References}

1. Department of Census and Statistics. Census of population and housing 2001, Sri Lanka: Kalutara district report, 2004, 723 .

2. WHO. Guidelines for drinking water quality. www.who.int. 122-144c.

3. Department of Census and Statistics. Household Income and Expenditure Survey 2006/2007, 53.

4. Mertens TE, Fernando MA, Marshall TF, Kirkwood BR, Cairncross S, RadalowiczA. Determinants of water quality, availability and use in Kurunegala, Sri Lanka. Annals of Tropical Medicine and Parasitology 1990; 41: 89-97.

5. Bureau of Sri Lanka Standards. Specification for potable water, part 2: bacteriological requirements. SLS 614, part 2, 1983 (with amendments approved in 1988).

6. Wickramasinghe WA, Widanapathirana ND, Vijayabandara GD, Karunathilake IM. Are tsunami survivors satisfied with the provision and quality of healthcare they received? Asia Pacific Journal of Public Health 2007; 19: 35-9.

7. Rathnayake TL, Rathnyake RMUK. How safe is our drinking water? Journal of the Ruhunu Clinical Society 2008; 15: 17-9. 